\title{
Embedded Path and Countermeasures of Yimeng Folk Song Teaching in Music Education
}

\author{
ShiYun Li \\ Feixian College in Linyi University, Linyi, Shandong province, China \\ 15165519838@163.com
}

Key Words: Yimeng Folk Song; Teaching; Countermeasures; The Path

\begin{abstract}
Faced with the present situation of poor Yimeng folk song teaching in music education, this paper explores the embedded path and countermeasures of Yimeng folk songs, in order to improve students' comprehensive quality by making a theoretical and practical study on the embedded teaching of Yimeng folk songs. This paper also provides a range of services for the high-quality talents, so as to cultivate Yimeng spirit and international vision and adapt to the need of current education reform.
\end{abstract}

\section{Introduction}

In recent years, the problems of localization in school music education have attracted more and more attention in the academic field. Meanwhile, some scholars have made investigation into the present situation of folk song teaching in specific regions or ethnic groups during the process of school music education. As early as the beginning of the 20th century, kodak's Hungarian composer and music educator were proposed and established by the national indigenous music language as a music education philosophy of teaching content and teaching system, and the local music teaching in China nowadays is still in the advocacy of infancy.

As an important part of local music in Shandong Province, Yimeng folk songs are relative to the opera, rap, dance, instrumental music and are more suitable for the school music education. With the domestic advocacies to carry forward the traditional culture and protect the intangible cultural heritage, the local government and relevant departments of local music have a good sense of protection and inheritance, but they have extreme weak consciousness of local folk heritage. Local schools are lack of strong supports. In terms of traditional music cultural inheritance, Linyi cultural departments mostly focus on data sorting and collecting, folk activities, music performance, publicity, but ignored the school inheritance base most directly and most widely, this as the cradle of young audience. Therefore, how to put more teaching content of folk songs into music education is an important subject for discussion.

\section{The Origin and Evolution of Yimeng Folk Songs}

Yimeng folk songs is a reflection of Yimeng people life during each period, it also reflects the high quality of Yimeng people's honesty, kind, the values and lofty stature. It is a condensation. It inspires generations of Yimeng children to make an unyielding and tenacious struggle, forge ahead, constantly overcome various difficulties and obstacles, and win victory with powerful spiritual force. 
Cohesion, Yimeng folk song is an important part of the excellent Chinese culture. It is also an important carrier of Yimeng culture, as well as an important manifestation of Yimeng spirits.

Yimeng folk song has a long history. Yimeng People are forthright,sincere and optimistic, so Yimeng folk songs are filled with a witty humor in interest, lively, presenting the extensive bold, exquisite and indirect merger characteristics. In the Southern Song Dynasty of reed, the king "is considered to be the representative of northern folk song. Since the Ming and Qing dynasties, Rapid development has a far-reaching influence on the development of music art genres in Yimeng Especially in the Anti-Japanese War and the China's War of Liberation, Yimeng people had created many popular revolutionary songs. The Yimeng minor spread throughout the whole country, and they were "led by the Communist Party", affecting the generations and being still promoted throughout the country. After the founding of new China, Yimeng folk song had entered a new stage of development, and Yimeng people inherited the tradition and carried forward the Yimeng spirit . At the same time, they understood life deeply, gave new contents to folk songs, created a large number of new ideas and new style of music works, which reflected the roles of Yimeng people in the socialist civilization construction, such as "My hometown Yimeng", "Good who don't say my hometown" and so on. In addition, tune ups and downs of flower drum, song and dance with rich contents of five major, have injected new vitality to the development of Linyi folk song.

\section{The Significance of Yimeng Folk Song Teaching}

Yimeng mountain area has a long history of ancient civilization, at the same time it has also given birth to rich and colorful folk songs. Yimeng People are forthright, sincere and optimistic, Yimeng folk songs are filled with a witty humor, and they have simple and lively style. It presents the extensive bold, exquisite and indirect merger characteristics. Tonality, minor, divertimento, minor or major nursery, flower drum, and so onwith rich genre, are handed down from the original ecological folk song, including the most widely minor songs in Yimeng mountain area, and it reserves one of the biggest folk songs. For example, "Yimeng minor", "good who don't say my hometown" and so on have a strong artistic appeal and distinctive personality. Yimeng folk songs and even the Linyi primary and secondary school music teaching is an important part of classroom teaching in Linyi universities. Yimeng folk song teaching can cultivate students' sentiment, cultivate their aesthetic temperament and interests, and promote the comprehensive development of students' body and mind. The development of Yimeng folk song teaching vigorously promotes the reform of music classroom teaching structure, makes the classroom teaching content develop "comprehensively" and "diversely", and improves the teaching quality of music. The Yimeng folk song teaching with other teaching contents may cooperate with each other, complement each other, and become an organic combination of the whole, and the teaching quality will become increasingly higher.

\section{Embed path and Countermeasures in Yimeng folk culture teaching}

To enable teachers to better teach Yimeng folk songs and spread Yimeng culture, researchers should extract the contents of Yimeng folk songs, and further study the teaching and countermeasures of Yimeng folk songs in music education.

Path Selection. For the time being, popular culture is so prevalent that Yimeng folk song may be a bit far away from the students. The primary task is to stimulate students' interest in the learning of Yimeng folk song. When it comes to the stimulation of students' interest, the students should be 
inspired to arouse their interest through certain methods and measures in this process. The following points should be paid attention to:

Choose the most obvious style of folk song: The types and quantities of folk song in the Linyi are extremely rich. Local style of folk songs shall be emphasized in particular when teachers choose the folk songs for the primary and secondary school students. The folk song is featured by its rich folk style. Since the students have more contacts with popular culture in today's society, the teachers may attract the students' attention and stimulate their desire to learn only when they let students have a strong feeling of national meaning. Therefore, the researchers recommend that teachers should choose a music style that represents the Yimeng mountain area and use folk songs with obvious geographical characteristics as a supplement, rather than selecting the original works or adaptations.

Select the folk songs with interesting contents of life: Yimeng folk song is a very important part in people's life. Yimeng folk songs are handed down with lots of folk, cultural and historical contents in the long history. Therefore, it is necessary to focus on the content of folk song and select appropriate folk songs during teaching. Meanwhile, it's important to stimulate students' interest in learning songs by choosing the interesting scenes of life. Students can have more affection for their hometown, people around them and motherland when they have a better understanding of diverse cultures, human geography and customs of new Yimeng. Especially during the process of teaching, the teacher should guide and introduce with passion to have a great influence on students, inspire them to love today's happy and enjoyable life, and feel proud of themselves.

Embed Countermeasures. Make the teaching purpose clear:

The first thing for teachers to do in teaching process is to make the teaching purpose clear. The purpose of Yimeng folk song teaching is to broaden the students' horizon, guide them to have a better understanding of Yimeng culture, and cultivate students' passion for Yimeng culture. Therefore, the difficult points in the teaching of folk songs should focus on the characteristics of songs in Yimeng Mountains and the "flavor" reflected by the songs. Teaching is not intended to require students to sing a song with perfection and Yimeng local flavor, or have an understanding of characteristics of the scale used in Yimeng folk songs. Its main points lie in the enhancement of self-awareness and identity of socialist culture in the diversity and unity of the Chinese nation. What's more, folk song teaching aims to achieve the support from Yimeng culture for the spiritual motivation and intellectualism.

Exert the teachers' roles in guiding: Nowadays, city life is getting more and more complicated, and diverse and pop culture is visible in the students' life. As a part of traditional Chinese culture, it may be difficult for students to accept and lile Yimeng folk songs within a short time. Therefore, the teacher should exert their roles in guiding the students. When it comes to the Yimeng folk teaching, the teacher should pay attention to the characteristics of stage and guide students in different grades with different angles and approaches. When referring to the primary school teaching, students' psychological characteristics should be paid attention to and the teaching should be taught from the song itself and then Yimeng cultural education awareness by musical transmission. When it comes to the level of middle-school teaching, it's necessary to cultivate students' world and life view because students have matured psychologies. It is essential to put students think, inspire them to pay attention to the Yimeng folk song and actively learn about the Yimeng folk song from the deep and historical perspective of Yimeng spirit and Yimeng culture.

Value the teaching of historical tradition and folk culture: Folk song teaching shall focus on the nation's history, culture, folk customs and other knowledge. The teacher helps the students build up 
national consciousness through folk songs. Therefore, in the folk song teaching, teachers should vigorously combine deep cultural background with the means of today's technology. It is beneficial to guide the students to know more about the folk songs by fusing the modern and traditional songs. To inherit folk culture and make students more visualized and specialized in the music, students can be given close touch with many means in terms of folk songs flash animation, the cut of movie plot or scene, and folk music, and so on.

\section{Conclusion}

The main line in the culture teaching of Yimeng folk song should focus on the teaching and appreciation of folk song. This kind of teaching can help students understand the meaning of folk music and the value reflected in the human art activities more directly through specific musical materials. The culture teaching of Yimeng folk song can also broaden the students' horizons in music and give the strong feeling of love towards ethnic folk songs and folk music. Meanwhile, the cultural teaching of Yimeng folk can cultivate students' music sensibility, taste, expression and creativity.

\section{Acknowledgement}

This paper is the phased research fruit subordinated to "The Embedded Study of Yimeng Folk Song Teaching in Pre-school Education" (project number: 15SDJ009) in the research of education and teaching by young teacher in Shandong Province. Teaching reform project in Linyi University "Building and Research of moral teaching system under the superiority of Yimeng cultural resources" (project number: 67) is to provide funding support.

\section{References}

[1]Miao Jing.Clearing up the Doubts on Yimeng Mountain in Minor [J].Music Study, 1980.3

[2]Wang Huihui.The Inheritance and Creation of Yimeng Folk Songs' Style [D]2014. The Post Graduates' Academic Degree Thesis in Qufu Normal University.

[3]Li Fangqin.The Study on the Inheritance and Popularity of Yimeng Folk Song [J], Broadcast Music Choice,2012.6

[4]Miao Jing. Clearing up the Doubts on Yimeng mountain in Minor [J]. Music Study,1980.3

[4]Wu Zhuang. Yimeng Mountain in Minor and its Communication Study [D], 2010. The Post Graduates' Academic Degree Thesis in Nanjing University of The Arts.

[5]Li Yanping. The Style of Linyi Folk Song and its Inheritance. [D], 2011.The Post Graduates' Academic Degree Thesis in Jiangxi Normal University.

[6]Guo Ping. The Study on the Construction and Application of Shandong Folk Song in the Primary and Secondary School Music Teaching. The Post Graduates' Academic Degree Thesis in Lu Dong University.

[7] Qi Jinfeng. The Present Situation of Shandong Folk Song and its Countermeasures of Inheritance in Shandong Province.[J], Northern Music.2014.8

[8]Ye Sheng. The Present Situation and Outlet of Folk Songs' Teaching [J]. Journal of Zhengzhou Municipal Committee of the CPC Party School. 2008.5 
[9]Qi Jinfeng. Introduction to the Implementation of Aesthetic Education in Folk Songs' Teaching [J]. Journal of Jichang College. 2008.1

[10]Wu Haihua. Exploration of Xiangxi Folk Songs in Music Teaching Practice [J]. Explorations in Music. 2012.2 